\title{
SOUTHWARD DISPLACEMENT OF THE DISTRIBUTION OF GLACIATION DURING THE THREE MAXIMA OF THE \\ LAST ICE AGE
}

\author{
By Nils-Axel Mörner \\ (Geologiska Institutionen, Universitet Stockholms, Box 68or, I I 386 Stockholm, Sweden)
}

\begin{abstract}
The Laurentide and Fennoscandian ice sheets had three major glaciation maxima during the Last Ice Age. All data from the southern margins of the ice sheets indicate that these maxima, as well as minor fluctuations, were synchronous. The same synchroneity is supposed to apply also for correlations between fluctuations on the north and south margins, which reveal a continuously southward displacement of the distribution of glaciation during the Last Ice Age. This southward displacement explains the saw-tooth pattern of ${ }^{18} \mathrm{O}$ records from deep-sea cores in which the first glaciation maximum is under-represented due to its distribution more towards the north. The synchroneity is consistent with a global climatic control of the stadial/interstadial changes and with the recorded global eustatic changes. The southward displacement of glaciation seems to be a general rule also applicable to earlier Pleistocene glaciations.
\end{abstract}

Résumé. Deplacement vers le sud de la distribution de la glaciation pendant les trois maxima du Dernier Age Glaciaire. Au cours du Dernier Age Glaciaire, les calottes glaciaires de Laurentide et Fennoscandian ont eu trois principaux maxima. Toutes les observations faites aux franges méridionales de ces calottes indiquent que ces maxima, ainsi que leurs petites fluctuations, ont été synchrones. On suppose que cette simultanéité est également valable pour des corrélations entre les fluctuations sur les franges nord et sud, qui révèlent un déplacement continu vers le sud de la distribution de la glaciation au cours du Dernier Age Glaciaire. Ce déplacement vers le sud explique l'allure en dents de scie des enregistrements de la teneur en ${ }^{18} \mathrm{O}$ provenant de carottes profondes dans lesquelles le premier maximum de la glaciation est sous-représenté en raison de sa distribution plus septentrionale. La simultanéité est une hypothèse cohérente avec un contrôle global par le climat, des changements stade glaciaire/stade interglaciaire, et avec les changements eustatiques globaux qu'on a enregistré. Le déplacement vers le sud de la glaciation semble être une règle générale également applicable aux glaciations précédentes du Pléistocène.

Zusammenfassung. Südverlagerung der Vereisung während der drei Maxima der letzten Eiszeit. Während der letzten Eiszeit hatten der Laurentidische und der Fennoskandische Eisschild drei grössere Vereisungsmaxima. Alle Daten über die Südränder dieser Eisschilde zeigen, dass diese Maxima, ebenso wie kleinere Schwankungen, synchron waren. Diesselbe Gleichzeitigkeit lässt sich für die Wechselbeziehungen zwischen Schwankungen an den Nord- und Südrändern annehmen, woraus eine kontinuierliche Südverlagerung der Vereisung während der letzten Eiszeit hervorgeht. Diese Südverlagerung erklärt das Sägezahn-Muster von ${ }^{18} \mathrm{O}$-Aufzeichnungen aus Tiefsee-Bohrkernen, in denen das Maximum der ersten Vereisung infolge von deren nördlicherer Lage schwächer zum Ausdruck kommt. Die Gleichzeitigkeit ist im Einklang mit einem weltweiten Ablauf der stadialen und interstadialen Klimaschwankungen und mit den festgestellten eustatischen Schwankungen. Die Südverlagerung der Vereisung scheint sich als allgemeingültig auch auf frühere pleistozäne Vereisungen anwenden zu lassen.

\section{INTRODUCTION}

In a recent paper (Mörner, I 974), I put forward the theory that the European and North American ice sheets of the Last Ice Age were continuously displaced southward during the three main glaciation maxima and that this may explain the shape of ${ }^{18} \mathrm{O}$ curves obtained from deep-sea cores (e.g. Emiliani, r 966).

Broecker and van Donk (I970) suggested that the saw-tooth pattern of the ${ }^{18} \mathrm{O}$ curves reflect "gradual glacial buildups". However, all glacial records clearly indicate that this is not the case but that the Last Ice Age is characterized by three major glaciation maxima of roughly the same size (Mörner, 197I, I972[a], [b]) though-as suggested by the author in the above-mentioned paper (Mörner, 1974) - with a continuously southward displacement of the glacial distribution (the centre and margins).

\section{Discussion}

Numerous studies (e.g. Gross, I967; Mörner, I970, I972[b], ı973; Dreimanis and Karrow, 1972; Mörner and Dreimanis, I973; Dreimanis and Raukas, I975) have documented that not only do the major stadial/interstadial changes, but also the second-order stadial/interstadial changes during the late Wisconsin-Weichselian, show a remarkable correlation on a 
regional basis along the margins of the ice sheets as well as on an inter-regional basis between the European and North American ice sheets. However, almost all of the data referring to the Laurentide-Cordilleran and the Fennoscandian ice sheets come from the southern, southeastern and south-western margins of these ice sheets. The records from the northern margins and the north-south correlations were forgotten. Thanks to the studies by the Institute of Arctic and Alpine Research in Boulder, Colorado, a fairly detailed stratigraphy and chronology have been established for the Baffin Island region. Because the outermost glaciation limit during the late Wisconsin was found to have been formed at about 8 ooo B.P. in Baffin Island, because the margin of error in the dating for the older periods was large and because the first glaciation maximum was the largest, the second was the second largest and the third (at 8 oоо в.P.) was the smallest, Pheasant and Andrews (1972, 1973) and Andrews and others $(1972)$ arrived at the conclusion that the ice-marginal fluctuations at the northern and southern margins of the Laurentide ice cap were out of phase.

However, this north-south out-of-phase theory is disbelieved by the present author for the following reasons :

(I) Both first- and second-order stadial/interstadial changes, as reflected in glacial, climatic and eustatic fluctuations, show such a remarkable global correlation (Mörner, I970, I97 I, I972[b], I973) that they must be closely controlled by global climatic changes, which also would have affected the Arctic region.

(2) The major eustatic changes during the last 130 ooo years (Steinen and others, I973; Chappell, 1974) show major regressions and transgressions consistent with synchronous glacial changes.

(3) The smaller Fennoscandian ice sheet shows synchronous ice-marginal fluctuations all around the ice cap, but with the centre and margins continuously displaced southwestward (Mörner, 1974, I976).

It is therefore suggested that the Laurentide ice sheets underwent synchronous glacial volume changes, with the centre and margins continuously displaced southward and westward.

This gives the following south-north correlations: Sangamon interglacial = Flitaway interglacial, Pre-St. Pierre or Nicolet stadial (smallest) = Alikdjuak stadial (largest), St. Pierre interstadial = Quajon interstadial, early Wisconsin or Guildwood stadial = NonasiakNapiat stadial, mid-Wisconsin interstadial complex $=$ Nonasiak/Kreager interval, late Wisconsin stadial (largest) $=$ Kreager stadial with Cockburn maximum (smallest). Besides the southward displacement, there was a similar westward displacement.

The corresponding south-north correlations of the Fennoscandian ice sheet are as follows (Mörner, I974, fig. 2, I976): Eemian interglacial = Mikulinskiy interglacial, Pre-Brörup stadial (smallest) = first glaciation maximum (largest), Brörup-Pilgrimstad interstadial = Mologo-Shenska-Karuküla interstadial with a boreal transgression at the Kola Peninsula, early Weichselian or Anholt stadial = early Valday or Leningradskiy stadial, mid-Weichselian interstadial complex (Glumslöv interstadial) = Grazhdanskiy Prospekt interstadial with an Arctic to Arctic-boreal transgression at the Kola Peninsula, late Weichselian or Brandenburg stadial (largest) = late Valday (smallest).

Figure I gives a graph of the glacial volume changes of the Laurentide and Fennoscandian ice sheets during the Last Ice Age, including the regional north-south correlations and the inter-regional (trans-Atlantic) correlations. There are three major glaciation maxima (I-III). These maxima had roughly the same volume, though the distribution was different: migrating from north to south with time. Prior to 50000 B.P. the time-scale is so uncertain that no dates have been applied to the graph in Figure I.

Certainly, many details remain to be determined before a final picture is established of the glacial volume changes and areal distribution changes of the Laurentide and Fennoscandian ice sheets during the Last Ice Age. However, Figure I is believed to show the fundamental 


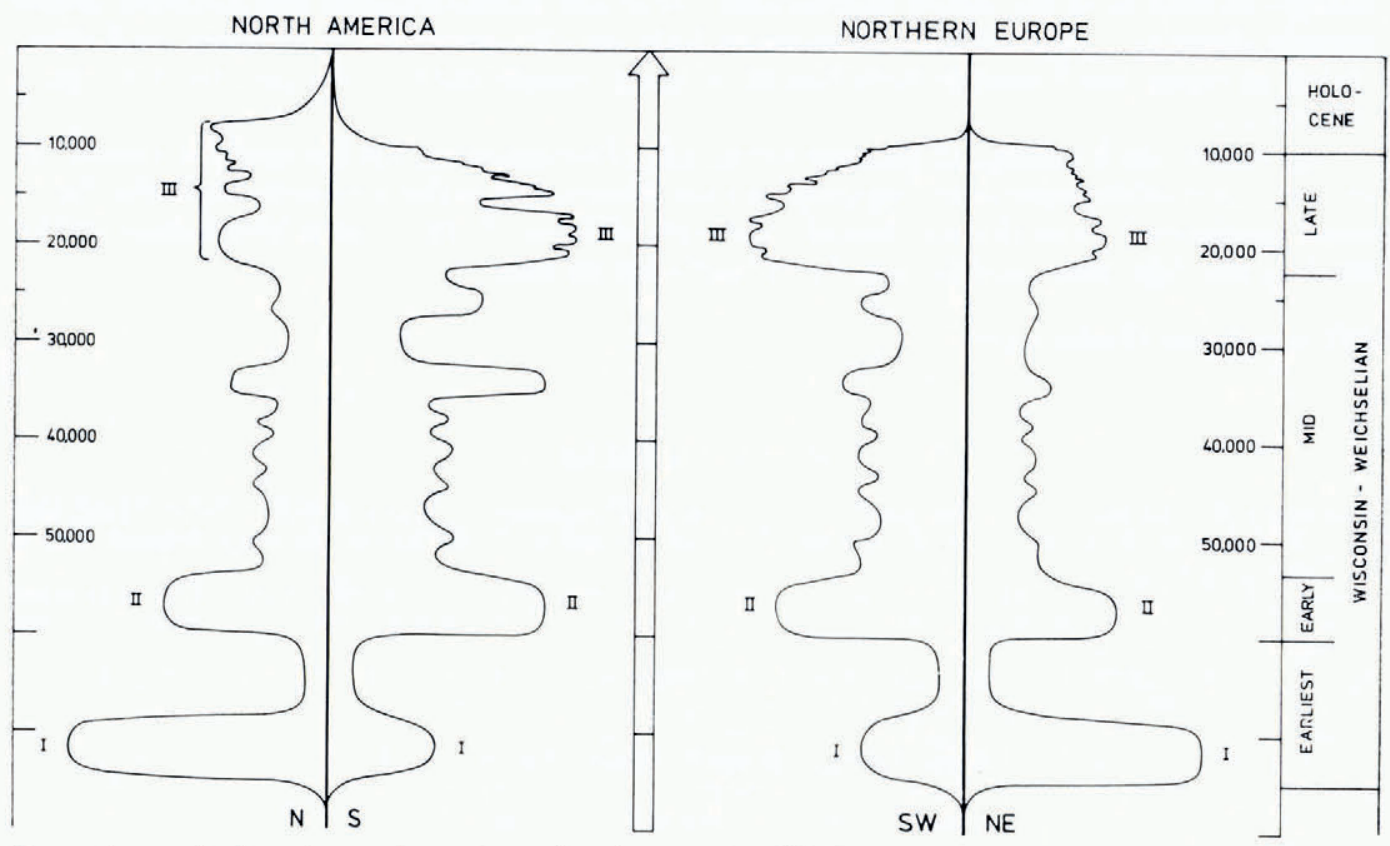

Fig. I. Ice-margin fluctuations at the northern and southern margins of the Laurentide and Fennoscandian ice sheets of the Last Ice Age. There are three synchronous glaciation maxima $(I-I I I)$, the distribution of which was continuously displaced southward. No time-scale is applied to the period prior to 50 oоo B.P. The details in the curves of the northern margins are not known but inferred from the analogy with the southern margin records. The deep-sea ${ }^{18} \mathrm{O}$ records can only be understood if they (besides temperature and glacial volume) also reflect this latitudinal distribution of glaciation, continuously displaced southward.

chronological correlations and extensional differences between the fluctuations along the northern and southern margins of the two continental ice sheets of the Last Ice Age. The corresponding geographical distribution of the Fennoscandian ice sheet has been given in a separate paper (Mörner, I974, fig. 2).

\section{Conclusions}

(I) The Laurentide and Fennoscandian ice sheets had three major maxima during the Last Ice Age. These maxima were of roughly the same size (disregarding the theory of "gradual glacial build-ups"). The distribution of these maxima was continuously displaced southward (south-westward in northern Europe and southward and westward in North America). This glacial migration explains the saw-tooth pattern of ${ }^{18} \mathrm{O}$ curves from deep-sea cores.

(2) As the ${ }^{18} \mathrm{O}$ records of the previous ice ages possess a similar saw-tooth pattern, it is likely that the southward migration of the glacial distribution is typical for an ice age, i.e. the accumulation starts in high latitudes and gives rise to an initial glacial phase centred far to the north, this is displaced southward during the subsequent stadial/interstadial changes, and finally reaches so far south that the subsequent warming causes a rapid end to the whole ice age (the "termination" by Broecker and van Donk (1970)).

(3) The ice-marginal fluctuations along the southern and northern margins of the Laurentide and Fennoscandian ice sheets were in phase (though of reversed order of magnitude). This is consistent with a global climatic control of the major stadial/interstadial 
changes as well as of the minor fluctuations. It is also consistent with the recorded glacial eustatic changes. (Furthermore, it seems to rule out the criticism by Andrews and others (1974) for using south-margin data instead of north-margin data to interpret the Greenland ${ }^{18} \mathrm{O}$ curve.)

(4) Much work remains to sharpen the details of the ice-marginal fluctuations around the ice sheets and of the corresponding geographical distribution of the ice sheets. Still, the northsouth synchroneity and the southward migration of the ice sheets seem to be fundamental for the Last Ice Age, and possibly also for the previous ice ages.

MS. received 20 October 1975

\section{REFERENCES}

Andrews, J. T., and others. 1972. Past and present glaciological responses to climate in eastern Baffin Island, [by] J. T. Andrews, R. G. Barry, R. S. Bradley, G. H. Miller and L. D. Williams. Quaternary Research, Vol. 2, No. 3, p. 303-14.

Andrews, J. T., and others. 1974. Comparison of the glacial chronology of eastern Baffin Island, East Greenland, and the Camp Century accumulation record, by J. T. Andrews, S. Funder, C. Hjort and J. Imbrie. Geology, Vol. 2, No. 7, p. $355^{-5} 8$.

Broecker, W. S., and Donk, J. van. 1970. Insolation changes, ice volumes, and the $\mathrm{O}^{18}$ record in deep-sea cores. Reviews of Geophysics and Space Physics, Vol. 8, No. 1, p. 169-98.

Chappell, J. 1974. Geology and coral terraces, Huon Peninsula, New Guinea: a study of Quaternary tectonic movements and sea-level changes. Geological Society of America. Bulletin, Vol. 85, No. 4, p. 553-7o.

Dreimanis, A., and Karrow, P. F. 1972. Glacial history of the Great Lakes-St. Lawrence region, the classification of the Wisconsin(an) stage, and its correlatives. International Geological Congress, twenty-fourth session, Canada, 1972, Sect. 12, p. 5-15.

Dreimanis, A., and Raukas, A. 1975. Did Middle Wisconsin, Middle Weichselian, and their equivalents represent an interglacial or an interstadial complex in the northern hemisphere? Bulletin of the Royal Society of New Zealand, No. 13, p. 109-20.

Emiliani, C. 1966. Paleotemperature analysis of the Caribbean cores P6304-8 and P6304-9 and a generalized temperature curve for the past 425,000 years. Fournal of Geology, Vol. 74, No. 2, p. 109-24.

Gross, H. 1967. Eine ganz ungewöhnlich vollständige Fernkonnektierung letzeiszeitlicher Schichtenfolgen von Nordamerika nach Europa. Quartär, Vol. 18, p. 157-61.

Mörner, N.-A. 1970. Comparison between Late Weichselian and Late Wisconsin ice marginal changes. Eiszeitalter und Gegenwart, Bd. 21, p. 173-76.

Mörner, N.-A. 1971. The position of the ocean level during the interstadial at about 30,000 B.P.: a discussion from a climatic-glaciologic point of view. Canadian Journal of Earth Sciences, Vol. 8, No. 1, p. 132-43.

Mörner, N.-A. I972[a]. The cold/warm changes during the last Ice Age: with special reference to the stratigraphy at Dösebacka and Ellesbo in southwest Sweden. Stockholm Contributions in Geology, Vol. 24, No. 4, p. $5^{1-77}$.

Mörner, N.-A. 1972[b]. World climate during the last 130,000 years. International Geological Congress, twenty-fourth session, Canada, 1972, Sect. 12, p. 72-79.

Mörner, N.-A. 1973. Climatic changes during the last 35,000 years as indicated by land, sea and air data. Boreas, Vol. 2, No. 1, p. 33-53.

Mörner, N.-A. I974. Ocean paleotemperature and continental glaciations. Colloques Internationaux du Centre National de la Recherche Scientifique, No. 219, p. 43-49.

Mörner, N.-A. 1976. Global correlations and Weichselian chrono-stratigraphy. (In Quaternary glaciations in the northern hemisphere. IGCP session in Bellingham, 1975, Report 3, p. 327-38.)

Mörner, N.-A., and Dreimanis, A. 1973. The Erie interstade. Memoirs. Geological Society of America, No. 136,

p. I 7-34.
Pheasant, D. R., and Andrews, J. T. 1972. The Quaternary history of the northern Cumberland Peninsula, Baffin Island, N.W.T. Part VIII, chronology of Narpaing and Quajon Fiords, during the past 120,000 years. International Geological Congress, twenty-fourth session, Canada, 1972 , Sect. 12, p. 81 - 88.

Pheasant, D. R., and Andrews, J. T. 1973. [The Quaternary history of northern Cumberland Pensinula, Baffin Island, N.W.T. Part 7.] Wisconsin glacial chronology and relative sea-level movements, Narpaing FiordBroughton Island area, eastern Baffin Island, N.W.T. Canadian Journal of Earth Sciences, Vol. Io, No. I 1 , p. I62I-4I.

Steinen, R. P., and others. 1973. Eustatic low stand of sea level between 125,000 and r 05,00o B.P.: evidence from the subsurface of Barbados, West Indies, by R. P. Steinen, R. S. Harrison and R. K. Matthews. Geological Society of America. Bulletin, Vol. 84, No. 1, p. 63-70. 